\title{
Assessing the regional impacts of Mexico City emissions on air quality and chemistry
}

\author{
M. Mena-Carrasco ${ }^{1,2}$, G. R.Carmichael ${ }^{3}$, J. E. Campbell ${ }^{4}$, D. Zimmerman ${ }^{5}$, Y. Tang ${ }^{3}$, B. Adhikary ${ }^{3}$, A. D'allura ${ }^{6}$, \\ L. T. Molina ${ }^{2,7}$, M. Zavala ${ }^{2,7}$, A. García ${ }^{8}$, F. Flocke ${ }^{9}$, T. Campos $^{9}$, A. J. Weinheimer ${ }^{9}$, R. Shetter ${ }^{9}$, E. Apel ${ }^{9}$, \\ D. D. Montzka ${ }^{9}$, D. J. Knapp ${ }^{9}$, and W. Zheng ${ }^{9}$ \\ ${ }^{1}$ Universidad Andrés Bello, Department of Environmental Engineering, Santiago, Chile \\ ${ }^{2}$ Massachusetts Institute of Technology, Department of Earth, Atmospheric and Planetary Sciences, Cambridge, MA, USA \\ ${ }^{3}$ The University of Iowa, Center for Global and Regional Environmental Research, Iowa City, IA, USA \\ ${ }^{4}$ University of California at Merced, School of Engineering, Merced, CA, USA \\ ${ }^{5}$ The University of Iowa, Department of Statistical and Actuarial Science, Iowa City, IA, USA \\ ${ }^{6}$ Arianet Environmental Modeling, Milan, Italy \\ ${ }^{7}$ Molina Center for Energy and the Environment, La Jolla, CA, USA \\ ${ }^{8}$ Universidad Nacional Autónoma de México, Delegación Coyoacán, México \\ ${ }^{9}$ National Center for Atmospheric Research, Boulder, CO, USA
}

Received: 8 October 2008 - Published in Atmos. Chem. Phys. Discuss.: 4 December 2008

Revised: 30 April 2009 - Accepted: 30 April 2009 - Published: 9 June 2009

\begin{abstract}
The impact of Mexico City (MCMA) emissions is examined by studying its effects on air quality, photochemistry, and on ozone production regimes by combining model products and aircraft observations from the MILAGRO experiment during March 2006. The modeled influence of MCMA emissions to enhancements in surface level $\mathrm{NO}_{\mathrm{x}}, \mathrm{CO}$, and $\mathrm{O}_{3}$ concentrations (10-30\% increase) are confined to distances $<200 \mathrm{~km}$, near surface. However, the extent of the influence is significantly larger at higher altitudes. Broader MCMA impacts (some $900 \mathrm{~km}$ Northeast of the city) are shown for specific outflow conditions in which enhanced ozone, $\mathrm{NO}_{\mathrm{y}}$, and MTBE mixing ratios over the Gulf of Mexico are linked to MCMA by source tagged tracers and sensitivity runs. This study shows that the "footprint" of MCMA on average is fairly local, with exception to reactive nitrogen, which can be transported long range in the form of PAN, acting as a reservoir and source of $\mathrm{NO}_{\mathrm{x}}$ with important regional ozone formation implications. The simulated effect of MCMA emissions of anthropogenic aerosol on photochemistry showed a maximum regional decrease of $40 \%$ in $\mathrm{J}\left[\mathrm{NO}_{2} \rightarrow \mathrm{NO}+\mathrm{O}\right]$, and resulting in the reduction of ozone
\end{abstract}

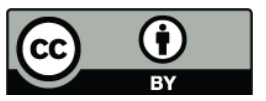

Correspondence to: M. Mena-Carrasco (mmena@unab.cl) production by $5-10 \%$. Observed ozone production efficiencies are evaluated as a function of distance from MCMA, and by modeled influence from MCMA. These tend to be much lower closer to MCMA, or in those points where modeled contribution from MCMA is large. This research shows that MCMA emissions do effect on regional air quality and photochemistry, both contributing large amounts of ozone and its precursors, but with caveat that aerosol concentrations hinder formation of ozone to its potential due to its reduction in photolysis rates.

\section{Introduction}

Megacities are defined as metropolitan areas with more than 10 million people (Gurjar and Lelieveld, 2005). This high concentration of urban dwellers generates challenging conditions for government: traffic congestion, solid and liquid waste disposal, drinking water supply, and bad air quality (Mayer, 1999; Lynn, 1999). Projections suggest that these problems will worsen as more people are migrating from rural to urban areas (Saier, 2008), especially in the developing world, where most new megacities are located. In addition to the adverse impacts on ecosystems and human health at local scales, megacities may also have noticeable impacts on

Published by Copernicus Publications on behalf of the European Geosciences Union. 
regional air quality and photochemistry (Mage et al., 1996; Guttikunda et al., 2001, 2003; Madronich, 2006).

Mexico City Metropolitan Area (MCMA), with a population of 20 million, is located at $2200 \mathrm{~m}$ above sea level and has complex constraining topography. Its physical properties generate conditions for low combustion efficiency and entrainment of pollutants. Additionally traffic congestion, a relatively old vehicular fleet, and the concentration of economic and industrial activity make it one of the most polluted cities in the world (Molina and Molina 2002; Molina et al., 2007). Megacities such as MCMA are also the source of considerable amounts of particulates, which affect photochemical reactions involved in ozone production and destruction (Carslaw and Carlslaw, 2001) mainly by altering the amount of radiation involved in photochemical reactions. For example a study in the MCMA showed that observed photolysis rates of $\mathrm{NO}_{2}$ at an urban site were $10-30 \%$ lower than at a nearby rural site (Raga et al., 2001). Model sensitivity studies in Asia and North America have shown that regional photochemistry can be altered by as much as $20 \%$ in the presence of aerosol (Tang et al., 2003; Li et al., 2005).

An intensive atmospheric chemistry measurement campaign denominated MILAGRO (Megacity Initiative: Local and Global Research Observations) (Fast et al., 2007; Molina et al., 2008) was carried out during March, 2006, collecting chemical and meteorological data in the MCMA and surrounding areas. Besides the use of ground-based measurement platforms, the campaign included multiple aircrafts: DC-8, and J-31 supported by NASA, C-130 supported by NCAR-NSF, G-1 and B200 supported by DOE, and a Twin Otter supported by the US Forest Service and NSF. This paper focuses on the analysis of observations from the C-130 and DC-8. The spatial coverage, maneuverability and sampling strategies for these aircrafts were different. The C130 sampled near and within the city, performing zig-zags and spirals at multiple altitudes with an altitude range from 0-6.5 km above mean sea level (MSL), with most measurements being taken in Mexico City or the Gulf of Mexico. The DC-8 performed direct flights from Houston, TX, with limited spirals, and a higher altitude range $(0-12 \mathrm{~km}$ above MSL). With the different spatial coverage, these aircraft sampling strategies intended to evaluate the regional influence of MCMA emissions on a regional (C-130), and continental (DC-8) scale.

In this paper we examine the impact of MCMA's emissions on ozone production focusing on interactions between ozone precursor concentrations and photochemistry. Using a combination of observations and model sensitivity analyses we estimate MCMA's "air quality" footprint. The area required to provide water, food, energy and waste management services to a megacity has been defined as the ecological footprint, which has been estimated to be significantly larger than the city itself (Valentine and Heiken, 2000). Here we extend such analysis to look at the "air quality footprint" of the MCMA emissions, which we define as the geograph- ical extension of discernible enhancements (contributions) of concentrations and photochemical rates attributable to the MCMA.

\section{Methods}

\subsection{Model description}

\subsubsection{Meteorological and chemical transport model}

In this campaign we used the STEM-2K3 model (Carmichael et al., 2003) to carry out air quality forecasting simulations to provide support and context to aircraft observations during the campaign. This chemical transport model (CTM) features full chemistry calculations using a lumped species SAPRC99 chemical mechanism (Carter, 2000) in conjunction with the TUV(Tropospheric Ultraviolet Radiation Model) (Madronich et al., 1992) on-line photolysis model and the SCAPE II (Simulating Composition of Atmospheric Particles in Equilibrium aerosol solver(Kim et al., 1993, 1995, 2003). The calculation of the photolysis was two-way coupled with other chemical modules, including inputs of concentrations of aerosols and gas phase species, and outputs of 30 photolysis rates defined by the SAPRC99 mechanism. The STEM-2K3 model was driven by the WRF V2.1.2 (Weather Research Forecasting) meteorological model (Grell et al., 2005), using the NCEP (National Center for Environmental Prediction) Global Forecasting System (GFS) $1^{\circ} \times 1^{\circ}$ analyses for meteorological boundary conditions (NCEP, 2003). For this study the model simulations used two nested domains, the outer using a $60 \mathrm{~km}$ resolution, 100 cells in East-West direction, and 64 cells in North-South direction, with an inner domain using a $12 \mathrm{~km}$ resolution, 110 cells East-West, and 95 cells North-South. The model had 21 vertical layers, extending from the surface to $100 \mathrm{hPa}$, with 10 of the levels representing altitudes from surface to $1 \mathrm{~km}$ above the terrain. The Grell-Devenyi ensemble cumulus parameterization (Grell, 1995), the YSU planetary boundary layer parameterization (Hong et al., 2006), and the NOAH land surface model (NOAA, 2005) were used for the WRF runs. In addition, tagged non-reactive tracer calculations were performed to qualitatively assess the contribution of geographical areas and source categories (MCMA, Northern Mexico, Southern Mexico, Central America, Texas, Central America, Asia, South East United States, biomass burning, large point sources, total anthropogenic CO, biogenic $\mathrm{CO}$ ) to $\mathrm{CO}$ mixing ratios.

The simulation period was March 2006, with an additional one week spin-up.

\subsubsection{Emissions inventories and boundary conditions}

The model runs used a high resolution emissions inventory for the MCMA developed by Universidad Nacional Autónoma de México (UNAM) for 1999 (Tie et al., 2007), 
Table 1. Summary of total emissions for MCMA for base model run (modified from UNAM emissions inventory 1999).

\begin{tabular}{llllllll}
\hline Sector & $\mathrm{PM}_{10}$ & $\mathrm{PM}_{2.5}$ & $\mathrm{SO}_{2}$ & $\mathrm{CO}$ & $\mathrm{NO}_{\mathrm{x}}$ & $\mathrm{VOC}$ 's & $\mathrm{NH}_{3}$ \\
\hline Industry & 3916 & 651 & 3284 & 6443 & 9869 & 62756 & 196 \\
Services and area & 10801 & 1962 & 41 & 7731 & 5831 & 119109 & 13543 \\
Transportation & 4768 & 3748 & 3321 & 1777907 & 73986 & 101144 & 3775 \\
Vegetation & 1201 & 261 & N/A & N/A & 313 & 9683 & N/A \\
Total & 20686 & 6622 & 6646 & 1792081 & 89998 & 292692 & 17514 \\
\hline
\end{tabular}

which included speciated VOC which were lumped into the SAPRC99 VOC categories. Table 1 shows a summary of the emissions used in this study separated by sector. For surrounding areas of MC, south of $21^{\circ} \mathrm{N}$ the Emission Database for Global Atmospheric Research (EDGAR 2.0) $1^{\circ}$ resolution anthropogenic area emissions inventory for 1990 was used (Olivier et al., 2002). For the six states in Mexico that share a border with the US (Baja California, Sonora, Chihuahua, Coahuila, Nuevo León, and Tamaulipas) a $36 \mathrm{~km}$ resolution anthropogenic emissions inventory from the BRAVO (Big Bend Regional Aerosol and Visibility Observational) study (Kuhns et al., 2005) was used. Biomass burning emissions of $\mathrm{CO}$ were provided by the an ecosystem based wild fire emissions processor (Pierce et al., 2007) which is part of the RAQMS (Regional Air Quality Modeling System) model (Pierce et al., 2005). Biogenic emissions were estimated using BEIS 2 (Biogenic Emissions Inventory System) (Geron et al., 1994) that generates time-variable isoprene and monoterpene emissions driven by meteorological variables, in this case from WRF simulations

Chemical boundary conditions were obtained from the Model for Ozone and Related Chemical Tracers (MOZART) (Horowitz et al., 2003), which was run by NCAR at a $0.7^{\circ}$ resolution using MOPITT assimilated $\mathrm{CO}$ concentrations for the same modeling period (March 2006) (Pfister et al., 2005).

\subsection{Interpolation of observations}

Aircraft measurements provide a unique opportunity to collect three dimensional observations of multiple chemical and meteorological parameters. Plotting these observations along flight tracks allow us to infer outflow patterns from the cities. However, interpolating these observations horizontally highlight these patterns even more. In this study we interpolated aircraft observations using kriging (Krige, 1951) for the nearest 50 observations and an isotropic exponential semivariogram. Interpolations were performed using ArcView 9.2 Geostatistical Analyst. This method, which has been used before in interpolating point bias estimations for aircraft observations during INTEX-NA (Mena-Carrasco et al., 2007), is only valid if the uncertainty of the method (subject to the sampling strategy, and the data) is significantly lower than the range of the interpolated values, which was the case for the analysis presented below.

\section{Results and discussion}

The regional impacts of MCMA are analyzed in two different categories: impact on air quality levels (again, focusing on $\mathrm{O} 3, \mathrm{NO}_{2}$, and $\mathrm{CO}$ ) and impact on photochemistry. While interrelated, these impacts are analyzed separately to estimate various aspects of the air quality "footprint" of MCMA emissions, which we define as the geographical extension of discernible enhancements (contributions) on concentrations of pollutants, or on photochemical rates. Before any conclusions or results can be presented, it is necessary to establish that the model performance is adequate.

Table 2 shows a summary of some species correlation coefficients for ozone and some of its precursors support the conclusions drawn from this study. The base model run used in this study was the result of improvements of model performance after the forecast stage of the campaign, focusing on updating boundary conditions from global models and analyzing model bias associated to emissions inventory errors (and how ozone precursor errors were correlated to ozone errors) (Mena, 2007). In general the model does a good job in predicting the ambient levels of the trace gases (correlation coefficients of $\sim 0.6$ for all science flights), and in capturing the variability (i.e., the predicted and observed variability are very similar as measured by the ratio of the standard deviation divided by the mean values). Further details on the model performance can be found in a separate paper that focuses on model performance during the forecast stage, and improvements made by updating emissions inventories and boundary conditions. Indeed, it is apparent that there is room for further improvement. However, for the specific analyses illustrated in this paper, model performance was substantially better $(R>0.8)$ providing better support for our findings.

\subsection{Modeled contribution of MCMA to pollutants}

There are many ways to estimate the impact of the emissions from the MCMA. For this project the effects of MCMA on the regional distributions of pollutants calculated as the difference between mixing ratios of modeled species with and without MCMA emissions, normalized to mixing ratios without MCMC emissions. Figure 1 shows the mean daytime contribution of MCMA to near surface mixing ratios 
Table 2. Model performance statistics for selected species during MILAGRO. C-130 Platform. 0-6 km range, flights 1-13.

\begin{tabular}{|c|c|c|c|c|c|c|c|c|}
\hline & \multicolumn{2}{|c|}{$\mathrm{O}_{3}(n=4066)$} & \multicolumn{2}{|c|}{$\mathrm{CO}(n=3213)$} & \multicolumn{2}{|c|}{$\mathrm{C}_{3} \mathrm{H}_{8}(n=3936)$} & \multicolumn{2}{|c|}{$\mathrm{ARO}_{1}(n=1176)$} \\
\hline & Obs & Mod & Obs & Mod & & Mod & Obs & Mod \\
\hline Mean & 58.73 & 66.12 & 146.86 & 184.72 & & 1.98 & 0.27 & 0.34 \\
\hline $\mathrm{SD} /$ mean & 0.33 & 0.29 & 0.58 & 0.46 & & 1.84 & 2.00 & 2.68 \\
\hline$R$ & & 0.58 & & 0.67 & & 75 & 0.64 & \\
\hline \multirow[t]{3}{*}{ MNB } & & 0.10 & & 0.25 & & 07 & 0.26 & \\
\hline & \multicolumn{2}{|c|}{$\mathrm{NO}_{\mathrm{x}}(n=4226)$} & \multicolumn{2}{|c|}{$\mathrm{NO}(n=4259)$} & \multicolumn{2}{|c|}{$\mathrm{NO}_{2}(n=4312)$} & \multicolumn{2}{|c|}{$\mathrm{NO}_{\mathrm{y}}(n=3936)$} \\
\hline & Obs & Mod & Obs & Mod & Obs & Mod & Obs & Mod \\
\hline Mean & 0.82 & 0.51 & 0.16 & 0.12 & 0.65 & 0.38 & 2.99 & 3.57 \\
\hline $\mathrm{SD} /$ mean & 4.40 & 2.70 & 2.87 & 3.75 & 2.85 & 2.73 & 1.53 & 1.45 \\
\hline$R$ & & 0.70 & & 0.55 & & 0.71 & & 0.63 \\
\hline $\mathrm{MNB} \%$ & & -0.38 & & 2.1 & & -0.41 & & 0.19 \\
\hline
\end{tabular}

SD: standard deviation. MNB: Mean normalized bias percentage, calculated as mean bias divided by mean average times 100 . $\mathrm{ARO}_{1}$ : Based on SAPRC99 speciation, it is defined as the sum of benzene and toluene.
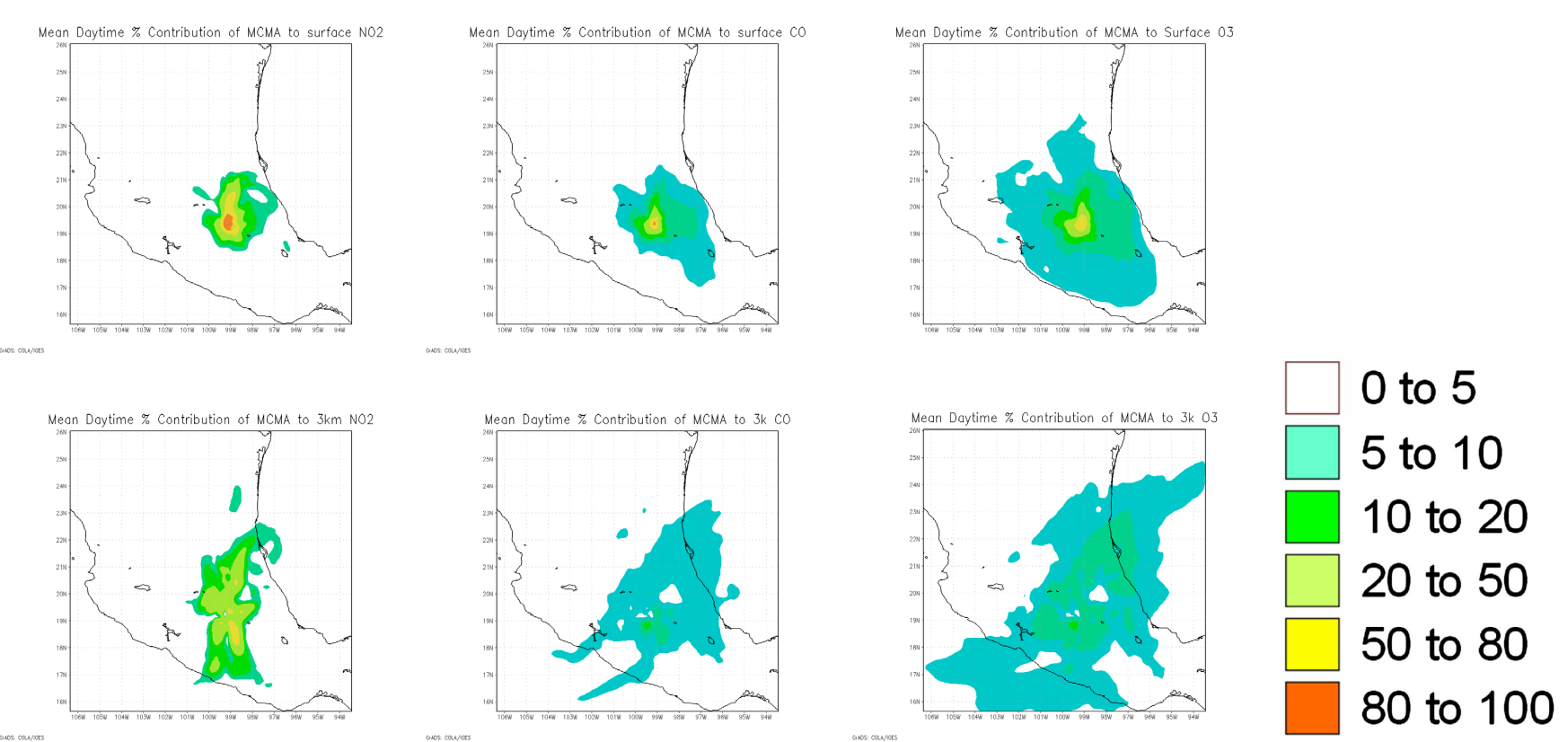

Fig. 1. Calculated effect of Mexico City on mean $18 \mathrm{Z}$ mixing ratios for March 2006. Top left: Mean $\%$ contribution to near surface $\mathrm{NO}_{2}$. Top center: $\mathrm{CO}$. Top right: $\mathrm{O}_{3}$. Bottom left: Mean $\%$ contribution to $\mathrm{NO}_{2}$ for $3 \mathrm{~km}$ above surface level. Top center: CO. Top right: $\mathrm{O}_{3}$. Contribution calculated as difference between simulated values with and without Mexico City emissions.

of $\mathrm{NO}_{2}, \mathrm{CO}$, and $\mathrm{O}_{3}$ for 1-31 March 2006. These results indicate that the impact varies by species, with the largest effects found for the primary pollutants. For example, locally (less than $100 \mathrm{~km}$ from the Distrito Federal) the near surface contribution of MCMA to the primary pollutants $\mathrm{CO}$ and $\mathrm{NO}_{2}$ is greater than $50 \%$. Significant contributions from MCMA emissions on near surface levels of $\mathrm{NO}_{2}$ and $\mathrm{CO}$ (20-50\% for $\mathrm{NO}_{2}$ and $10-20 \%$ for $\mathrm{CO}$ ) can extend $\sim 200 \mathrm{~km}$ north, based on model results. In the lower-mid troposphere ( $3 \mathrm{~km}$ layer, shown in bottom panels) smaller contributions of MCMA emissions to $\mathrm{CO}$ and $\mathrm{NO}_{2}(5-10 \%$ and $10-20 \%$ contribution, respectively) can extend up to $\sim 300 \mathrm{~km}$ north and south of the city, with those contributions to $\mathrm{NO}_{2}$ reaching Tampico). The MCMA contribution is highest for the short lived species (e.g., $\mathrm{NO}_{2}$ ), but it is also more geographically confined. In contrast, for longer-lived species (e.g., $\mathrm{CO}$ ), the regional emissions are higher, and the contributions from the MCMA are smaller, but are spread over greater distances. The MCMA contribution to ozone levels is qualitatively similar to those for $\mathrm{CO}$, and smaller than those for 
$\mathrm{NO}_{2}$. The magnitude and structure of the ozone response reflects non-linearities in the ozone chemistry.

A day to day analysis shows that these patterns present great variability in terms of the extension and the intensity of the contribution of Mexico City emissions on surrounding areas (focusing on $\%$ contribution to $\mathrm{NO}_{\mathrm{y}}$, which in a way serve as a tracer for $\mathrm{NO}_{\mathrm{x}}$ emissions). Comparing near surface contributions (Fig. 2) to mid troposphere contributions (Fig. 3) the MCMA influence is largest and most widespread at $3 \mathrm{~km}$ (with most of $\mathrm{NO}_{\mathrm{y}}$ in the form of PAN, not shown). Modeled contributions from 20 to $50 \%$ in this layer are shown to extend well outside the boundaries of the country, both into the Pacific Ocean and the Gulf of Mexico. The MCMA regions of influence vary day-by-day in terms of narrow and concentrated plumes (e.g., Fig. 3, 12 and 19 March) to more disperse features (e.g., 14 March). Narrow plumes on the $3 \mathrm{~km}$ layer occurred in 9 out of 31 modeled days, while more disperse plumes occurred in the remaining 22 days. Therefore stronger outflow from the city can be categorized as occasionally frequent. Further discussions of the MCMA plumes are presented below.

\subsection{8-19 March 2006 long range transport event}

Specific synoptic features, such as a prevailing high pressure system over the Gulf of Mexico, and a low pressure system over Northwestern Mexico can favor transport events that can extend the region of influence of MCMA emissions on a regional scale, i.e., the 18-19 March 2006 period in which persistent westerly and southwesterly winds created favorable conditions for distinct long range transport (Fast et al., 2007). An important question that MILAGRO set out to answer was over what geographic scales can the effects of the MCMA plume be identified? In this section we explore various methods to establish the spatial extent of the plume using observations and modeling products, focusing on 19 March 2006. On this day the $\mathrm{C}-130$ flew to intercept fresh emissions near the source, and then out into the Gulf of Mexico to intercept aged MCMA emissions (from previous days). This flight was chosen because while other flights do show similar results in concentration enhancements attributable to the MCMA closer to the city, this was the only day in which strong predicted outflow combined with a sampling strategy to capture the outflow over the Gulf of Mexico.

\subsubsection{Interpolation of observations along flight track to illustrate outflow plume}

Kriging was used to highlight the outflow pattern during the event, using $\mathrm{O}_{3}, \mathrm{NO}_{\mathrm{y}}$, and methyl tertiary-butyl ether (MTBE) observations, the latter is a gasoline oxygenate linked to mobile source emissions that has a half life of 3 to 6 days (Achte, 2002). The results are shown in the top panels of Fig. 4. Shading in the figures represents the uncertainty of the interpolation method, which depends on the geographi- cal distribution of the data. In this case uncertainty is substantially lower than the observations in the plume $(15 \mathrm{ppb}$, $1.5 \mathrm{ppb}, 5 \mathrm{ppt}$ for $\mathrm{O}_{3}, \mathrm{NO}_{\mathrm{y}}$ and MTBE respectively). This method works under the assumption that the sampling captures largely the horizontal geospatial variations of the chemical species and that over the duration of the observations that the geospatial distributions are constant in time. These conditions are satisfied as the sampling strategy for this flight was to look specifically at the MCMA plume, and the sampling horizontal velocity of the aircraft is roughly 20 times faster (mean value of $125 \pm 0.47 \mathrm{~m} / \mathrm{s}$ for a $95 \%$ confidence interval) than the transportation of pollutants (mean wind velocity of $6.79 \pm 0.15 \mathrm{~m} / \mathrm{s}$ for a $95 \%$ confidence interval). The top panels show plumes of $\mathrm{O}_{3}, \mathrm{NO}_{\mathrm{y}}$ and MTBE near MCMA and also off the coast of Texas. On this day the MCMA plume was being transported towards the north-northeast, and the C130 followed the plume to the coast. The flight continued out over the Gulf of Mexico and sampled the aged MCMA plume. The plume like structure is identified in the krieged fields and is similar to that predicted by the MCMA footprints, which are also shown in Fig. 4 (lower panels). These results suggest that the observation of the MCMA plume can be observed out to $900 \mathrm{~km}$. The center right panel shows the ratio of observed $\mathrm{NO}_{\mathrm{x}}$ to $\mathrm{NO}_{\mathrm{y}}$. This ratio is high in MCMA reflecting fresh emissions. The value decreases with distance from the megacity, as the plume photochemical ages. When the aircraft encountered MCMA plumes transported over the Gulf on the previous day the ratio increased. In these older $\mathrm{NO}_{\mathrm{y}}$ is mostly in the form of PAN, suggesting that the thermal decomposition of PAN may be an important source of $\mathrm{NO}_{\mathrm{x}}$, which contributes to additional ozone formation along the outflow, in agreement with work by Emmons (to be submitted).

\subsubsection{Time series of modeled and observed values along flight track}

Through the combination of the measurements and models it is possible to develop strategies to identify individual observations that are impacted by the MCMA. For example the model predictions of MCMA impact can be sampled along the flight paths, merged with the observational data, and then used as a filter to collect data that meet specified design criteria. An example is shown in Fig. 5, where observed and predicted $\mathrm{O}_{3}$ and $\mathrm{NO}_{\mathrm{y}}$ mixing ratios are plotted along the flight path for the 19 March flight discussed above. Each predicted data point is colored by the $\%$ contribution of the MCMA tracer to CO. The predicted values of $\mathrm{O}_{3}$ and $\mathrm{NO}_{\mathrm{y}}$ agree reasonably well $\left(R=0.72\right.$ for $\mathrm{O}_{3}$ and 0.76 for $\left.\mathrm{NO}_{\mathrm{y}}\right)$ with the observations and capture much of the observed structure and variability. The results indicate the contributions of the MCMA vary significantly along the flight path. Near the MCMA local emissions dominate as shown by the high MCMA contributions at 12:00-13:00 and 18:00-19:00 local time (LT). As as discussed above and shown in Fig. 4, 

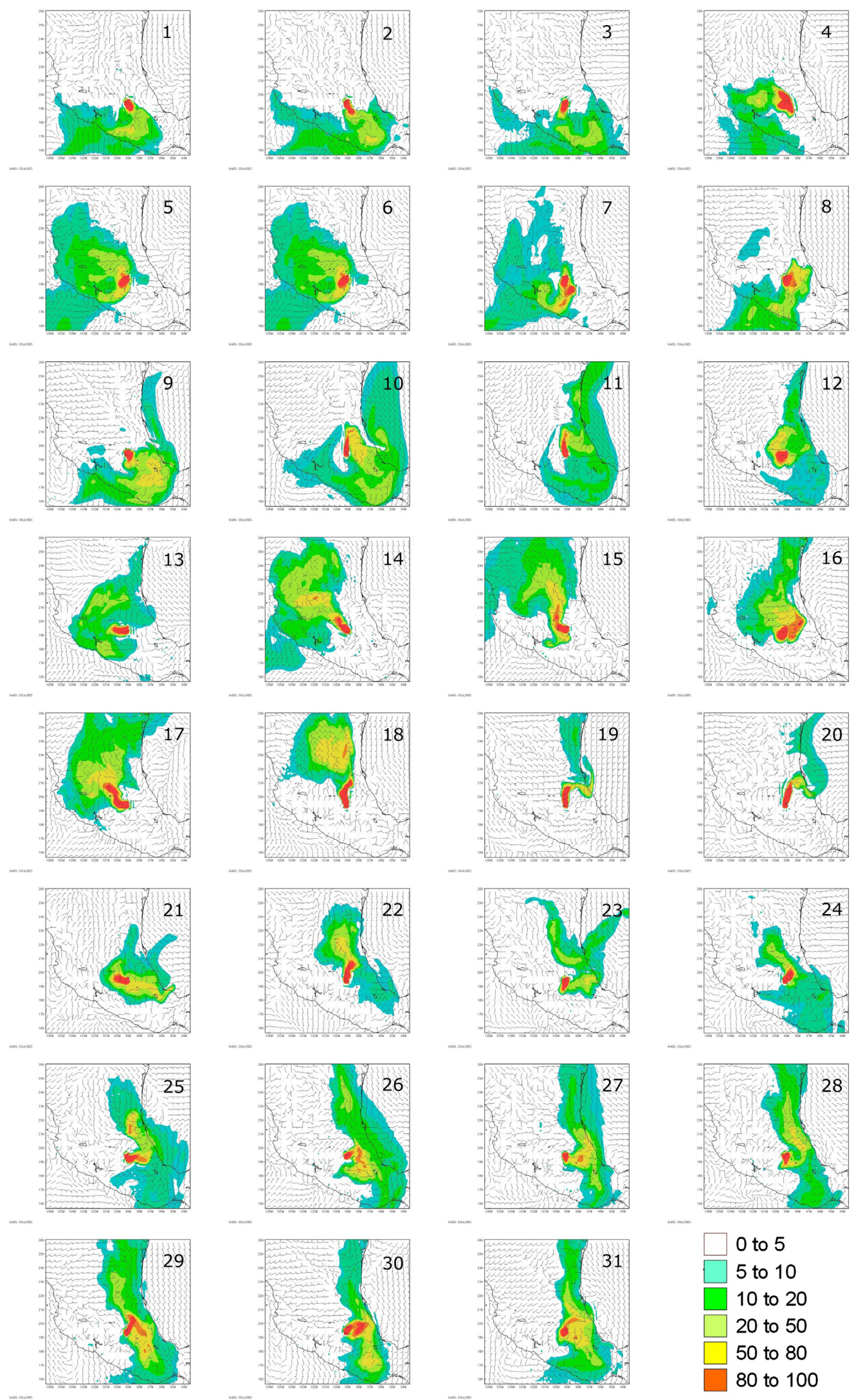

Fig. 2. Calculated effect of Mexico City emissions on $18 \mathrm{Z}$ mixing ratios of $\mathrm{NO}_{\mathrm{y}}$ for $1-31$ March 2006 , shown as the \% contribution for the near surface layer. Contribution calculated as percent difference between simulated values with and without Mexico City emissions. 


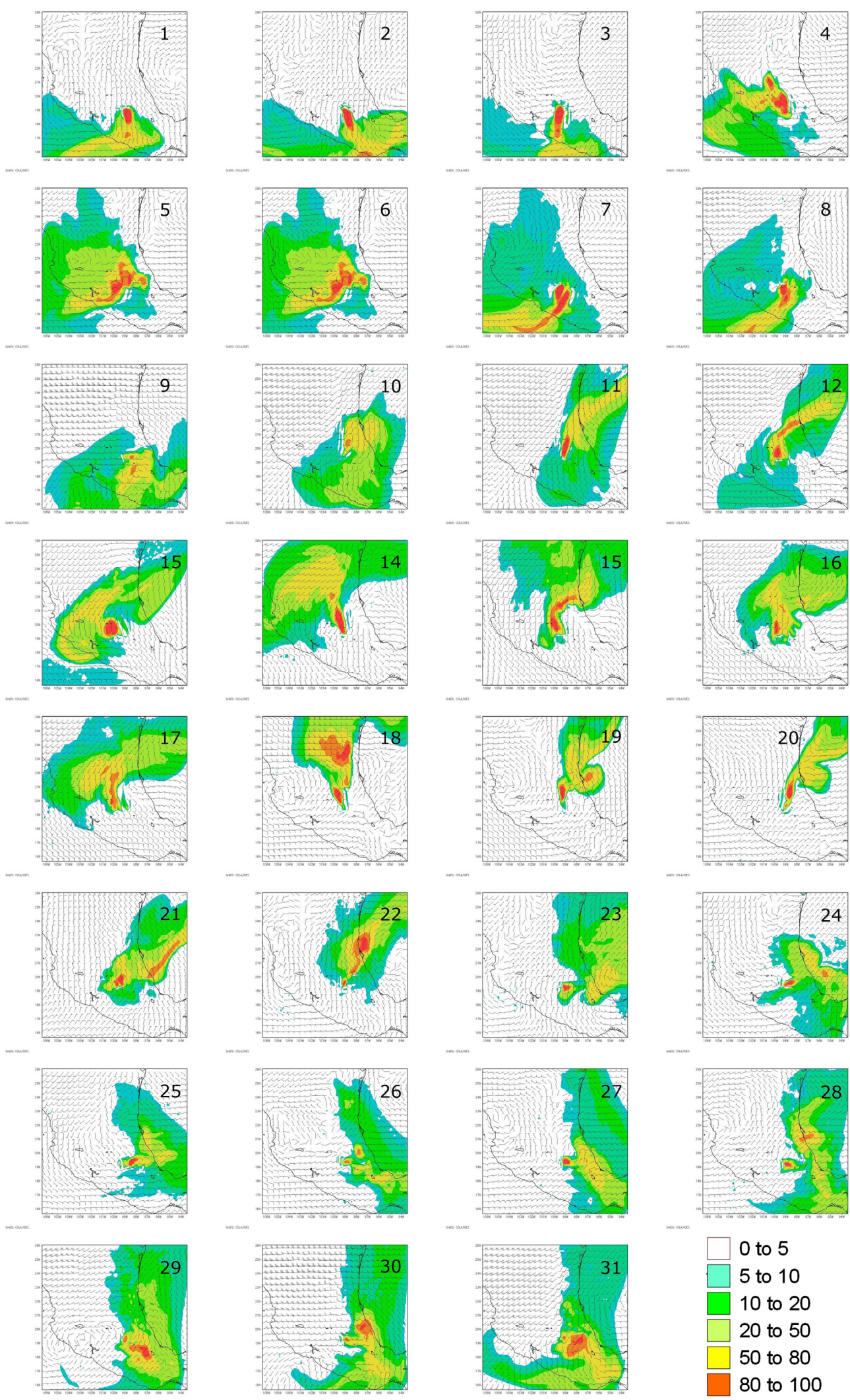

Fig. 3. Calculated effect of Mexico City emissions on $18 \mathrm{Z}$ mixing ratios of $\mathrm{NO}_{\mathrm{y}}$ for 1-31 March 2006, shown as the \% contribution for the $3 \mathrm{~km}$ above surface vertical layer. Contribution calculated as percent difference between simulated values with and without Mexico City emissions. 

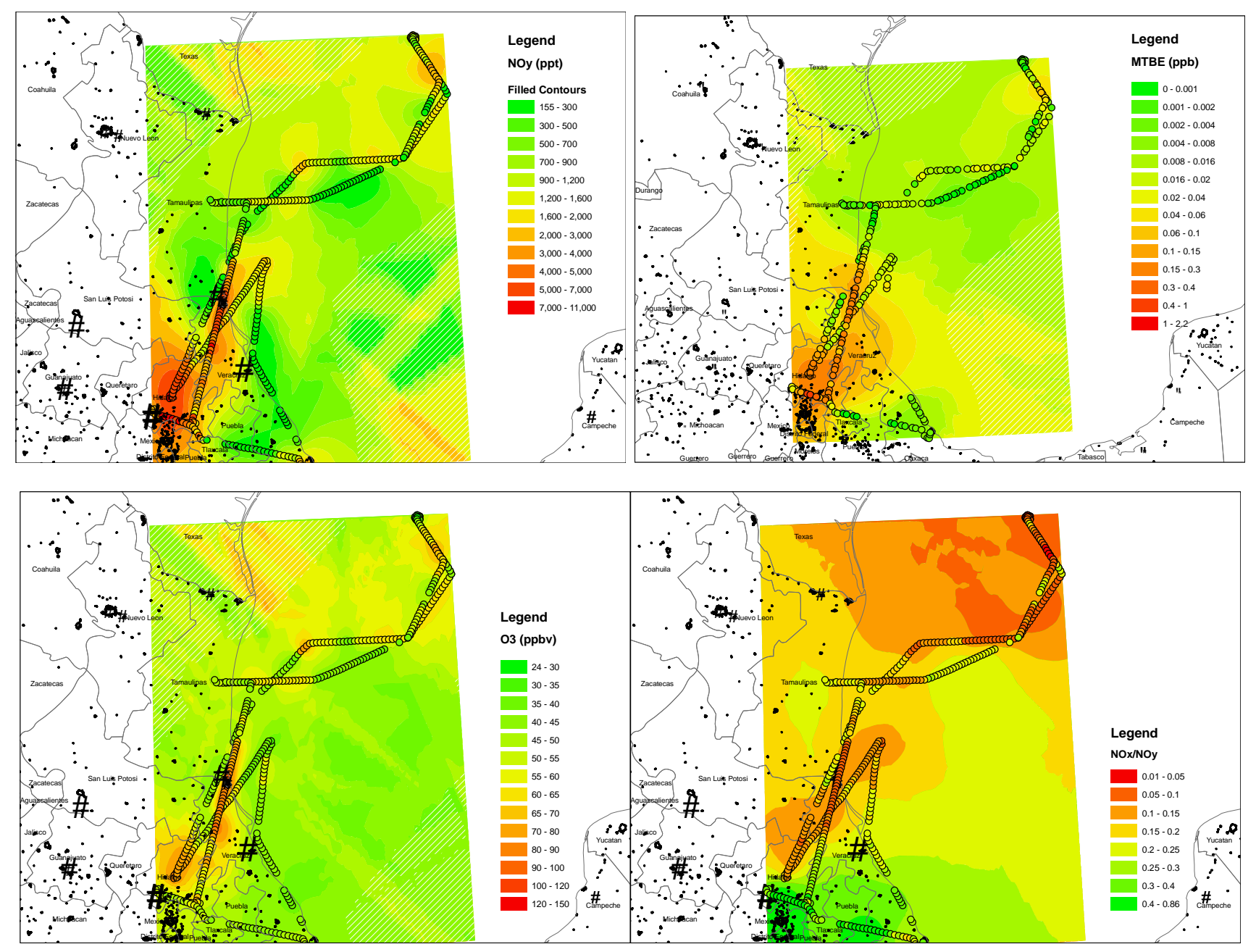

\% Contribution of MC to March 19, 2006 (212) $1-5 \mathrm{~km}$ NOy
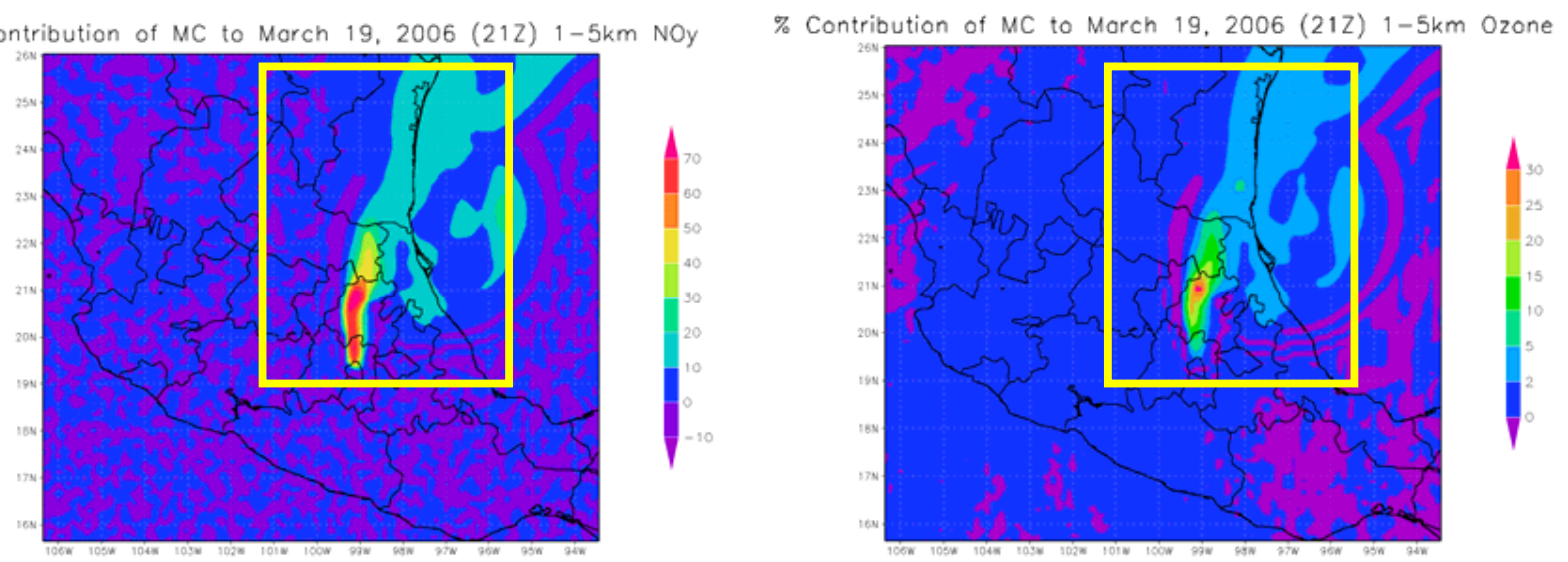

Fig. 4. Interpolated observations through kriging for C-130 19 March 2006 flight. Top Left: MTBE Right: $\mathrm{NO}_{\mathrm{y}}$. Center left: $\mathrm{O}_{3}$, Center right: $\mathrm{NO}_{\mathrm{x}} / \mathrm{NO}_{\mathrm{y}}$, Calculated effect of Mexico City on regional air quality. Shaded area represents method uncertainly for $\mathrm{NO}_{\mathrm{y}}(1500 \mathrm{pptv})$, $\mathrm{NO}_{\mathrm{x}}(800 \mathrm{pptv})$ and $\mathrm{O}_{3}(15 \mathrm{ppbv})$ Bottom Left: Simulated contribution to mean 1-5.4 km NO . Bottom Right: Simulated percent contribution to 19 March 2006 (21Z) 1-5.4 km mean ozone, calculated as the difference in mixing ratios with and without Mexico City anthropogenic emissions. 

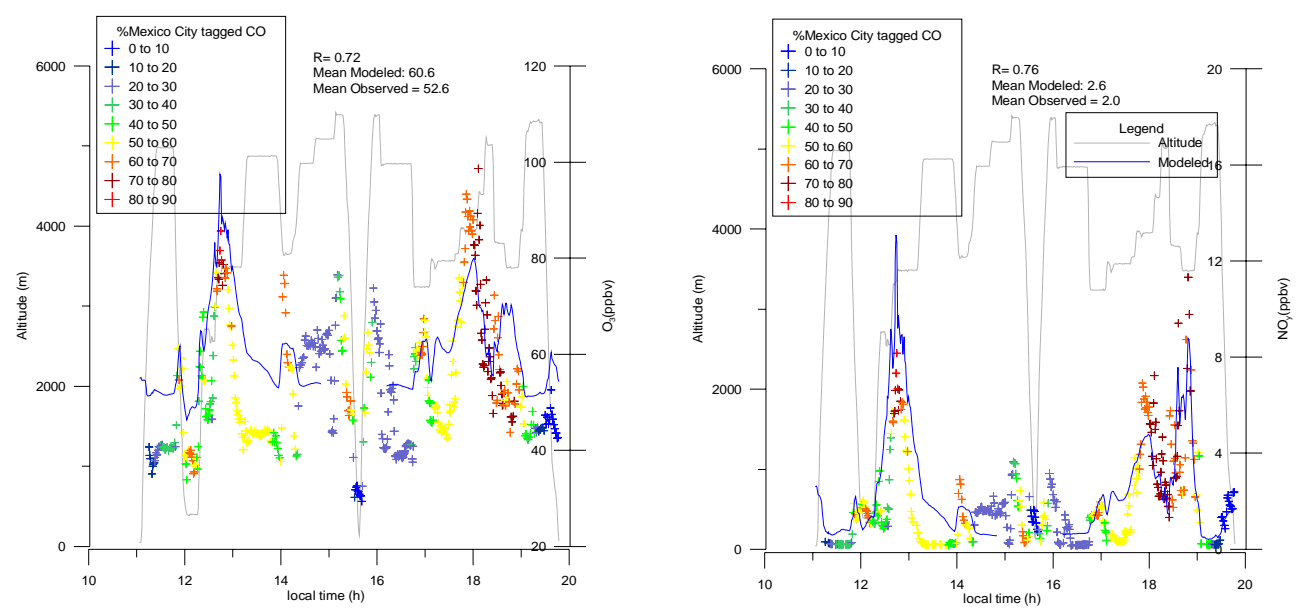

Fig. 5. Times series of observed and predicted $\mathrm{O}_{3}$ and $\mathrm{NO}_{\mathrm{y}}$ along 19 March $2006 \mathrm{C}-130$ flight track. Points are colored by the contribution of Mexico City tracer $\mathrm{CO}$ to total tracer CO. Left: $\mathrm{O}_{3}$ (ppbv), Right: $\mathrm{NO}_{\mathrm{y}}$ (ppbv).
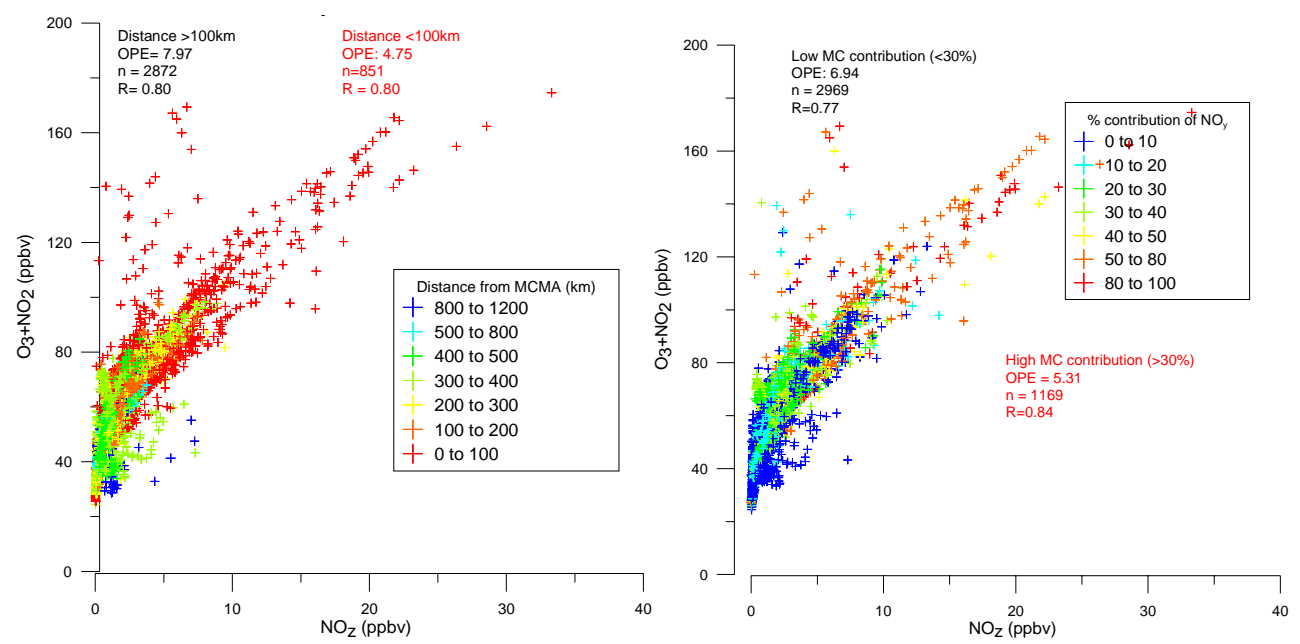

Fig. 6. Observed ozone production efficiencies, derived from $\mathrm{O}_{3}+\mathrm{NO}_{2}$ and $\mathrm{NO}_{\mathrm{Z}}$ observations as a function of distance (Left) and modeled influence of Mexico City emissions (Right) for all C-130 flights.

during this flight elevated levels of ozone and NOy $(60$ and $\sim 2$ ppbv, respectively) were observed off the coast of Texas. This sampling period corresponds to period 15:00-16:00 LT in Fig. 5. For these points the emissions from the MCMA show a $\sim 50-60 \%$ modeled contribution to CO. Application of this screening approach are presented in the following section.

\subsubsection{Impact of MCMA emissions on ozone formation and regional photochemistry}

The effect of MCMA emissions on ozone formation can be either as its contribution to precursors, or by its effect on the photolysis rates involved in ozone formation. To quantify this effect we calculate ozone production efficiency (OPE) (Kleinman, 2002), defined as the amount of odd oxy- gen vs. $\mathrm{NO}_{\mathrm{x}}$ lost (sum of odd oxygen $\mathrm{NO}_{2}+\mathrm{O}_{3}$ vs. $\mathrm{NO}_{\mathrm{z}}$ ). Observed ozone production efficiencies for all the $\mathrm{C}-130$ flights are shown in Fig. 6. The data are identified by distance from MCMA (left panel) and by contribution from MCMA emissions (right panel). Near the city, ozone production efficiencies are lower than at further from the city ( 4.9 vs. 7.9 respectively, calculated as the slope of the plot separated among observations within and beyond $100 \mathrm{~km}$ from the city). Similarly, categorizing observations with large MCMA influences (using over $30 \%$ modeled contribution to $\mathrm{NO}_{\mathrm{y}}$ as the metric for significant MCMA contribution) we see that OPE is lower than those with smaller MCMA influences (5.3 vs. 6.9 respectively). These effects are expected as high $\mathrm{NO}_{\mathrm{x}}$ mixing ratios, tend to form nitric acid $\left(\mathrm{HNO}_{3}\right.$, a component of $\left.\mathrm{NO}_{\mathrm{z}}\right)$ under a VOC limited ozone production regime (Tie et al., 2007), making ozone production less efficient. Also, while 

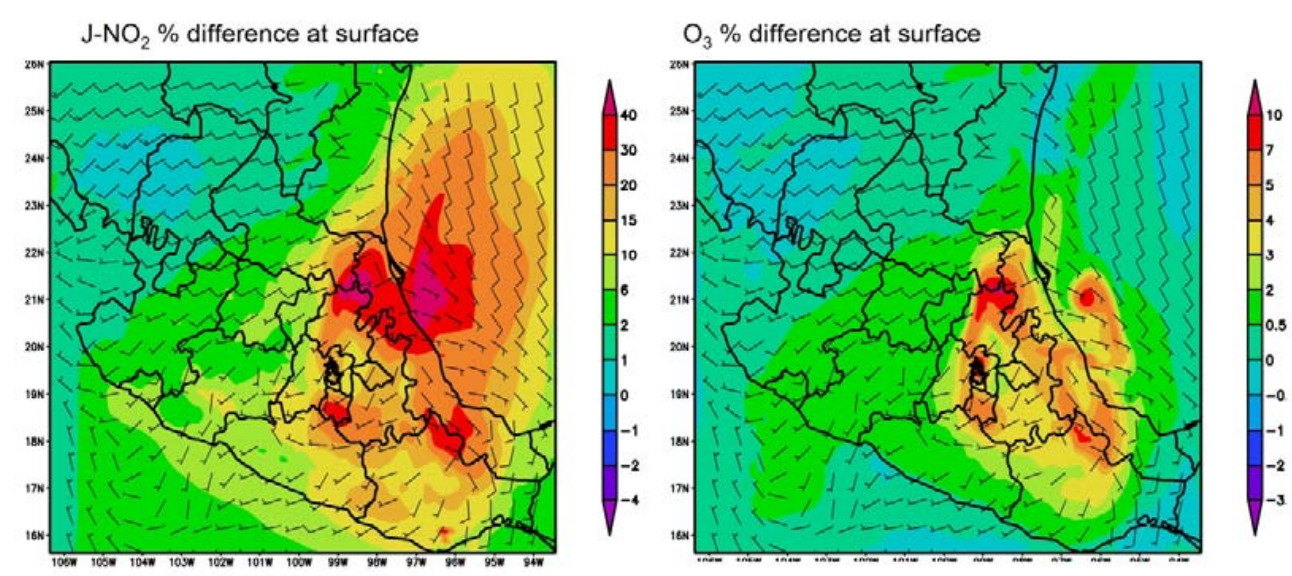

$\mathrm{J}-\mathrm{NO}_{2} \%$ difference at $3 \mathrm{~km}$
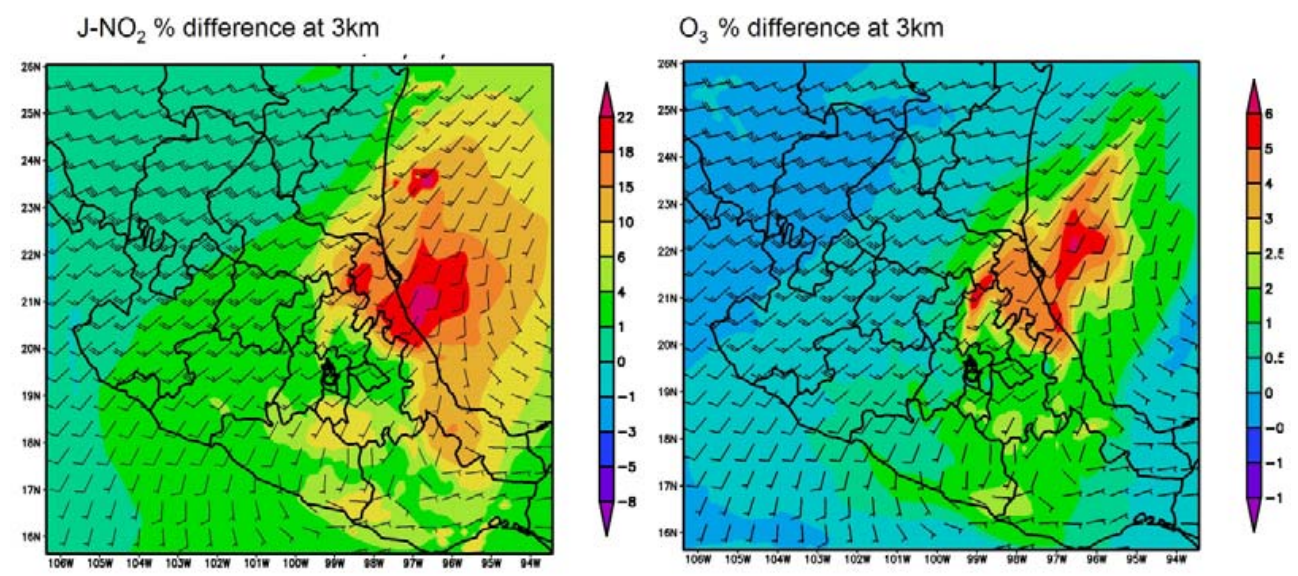

Fig. 7. Calculated modeled effect of aerosol loading on photolysis rate of $\mathrm{NO}_{2}$ and $\mathrm{O}_{3}$ formation calculated as difference between model runs with and without aerosol (NOAOD vs. base case) for $12 \mathrm{~km}$ STEM, 10 March 2006, at 21:00 UTC. Top panels calculated at surface layer; Bottom panels calculated at $3 \mathrm{~km}$.

the MCMA plume shows VOC limited conditions, it does still present large VOC concentrations (Karl et al., 2008) and as it ages forms PAN, hindering $\mathrm{O}_{3}$ formation locally, but downwind acts as a remote source of $\mathrm{NO}_{\mathrm{x}}$ refueling ozone formation (Emmons et al., 2009).

Another important consideration in regards to ozone production and photochemical activity is the role of aerosols. Mexico City is a large source of absorbing and scattering aerosol (Marley et al., 2007). The aerosols impact the photochemistry in various ways. One important impact is that the aerosol changes the photolysis rates. In order to evaluate the effect of MCMA aerosol on photochemistry and ozone formation, sensitivity runs were performed analyzing the difference between a full chemistry run and a run in which the effect of aerosol on the online calculated photolysis rates is excluded (No-AOD run). For this case we focused on the 10 March 2006 outflow event. The general features for this day are shown in Figs. 2 and 3. It was found that for $\mathrm{J}\left[\mathrm{NO}_{2}\right]$ (the most direct photochemical ozone formation reaction), aerosols were found to reduce the photolysis rates by up to $40 \%$ in areas downwind of MCMA to the NE, and reduce ozone mixing ratios by as much as $\sim 5-10 \%$. This amounts to changes in ozone levels between 5 to $10 \mathrm{ppb}$. The large regional extent of the effect of aerosols on the photochemistry is due to the fact that in megacities aerosol and ozone precursors are co-emitted and are transported together, leading to a prolonged influence on photochemistry (Tang et al., 2003).

However these impacts may indeed be underestimated, if we look at how the model captures the effect of aerosols on photolysis. If we try to show the spatial distribution of point bias calculations interpolated for all flights (Fig. 8) we see that photolysis rates are overpredicted between 10 to $50 \%$ especially near MCMA. These results suggest that the modeled effect of aerosol on photochemistry is most likely a conservative estimation. A major cause of the underestimation of the impact of aerosols may be due to the underprediction in emissions in wind blown dust and biomass burning, which are represented in the model with a high degree of uncertainty. Both dust and biomass burning aerosols were observed at high levels during this time period in and around the city. Thus high aerosol concentrations clearly contribute to low ozone production efficiency near the MCMA due to 


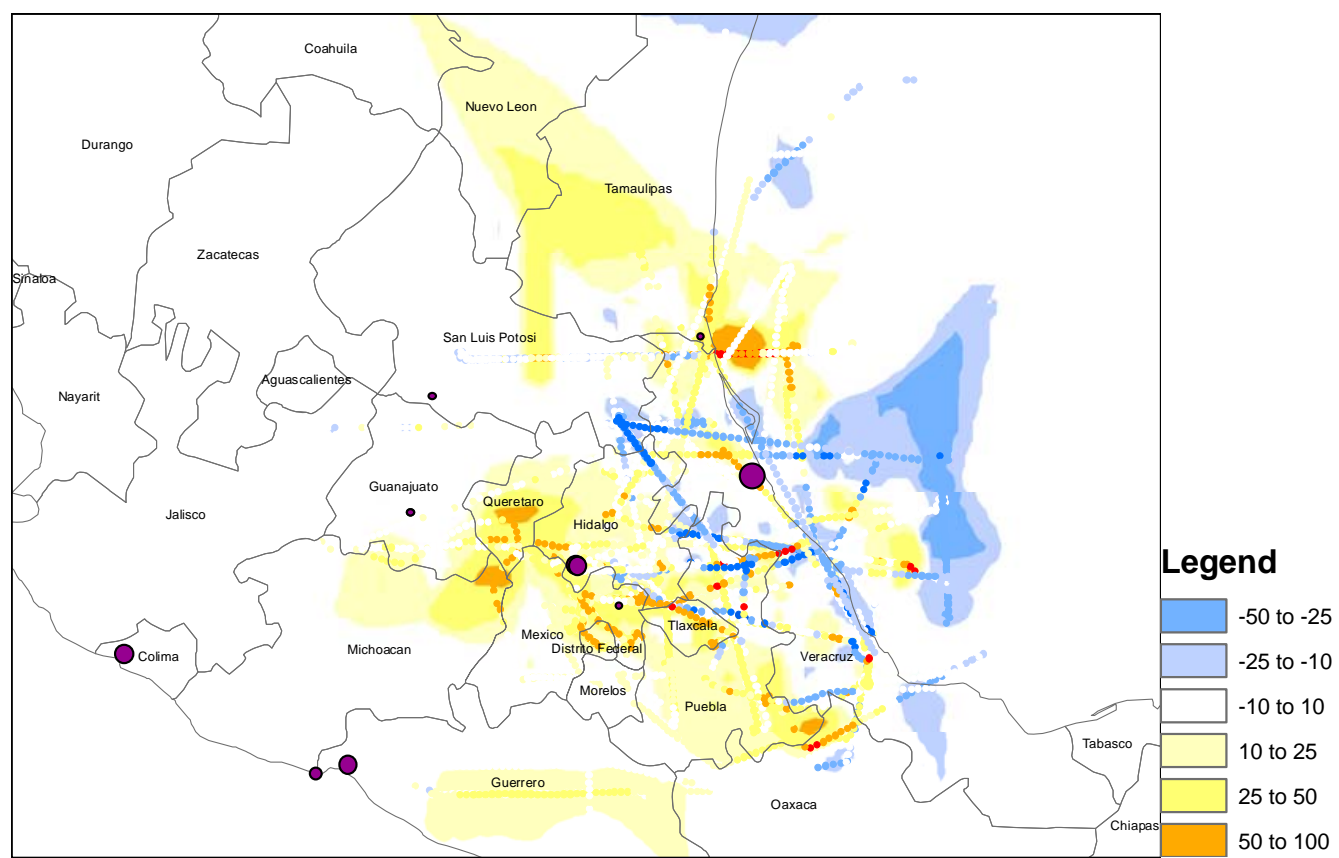

Fig. 8. Interpolated point percent bias of $\mathrm{J}\left[\mathrm{NO}_{2} \rightarrow \mathrm{NO}+\mathrm{O}\right]$ modeling for values extracted along $\mathrm{C}-130$ flight tracks using kriging, $n=3500$ for all science flights.

the reduction in photolysis rates, which extend $\mathrm{NO}_{\mathrm{x}}$ lifetime within the city. The low photolysis rates also increase the lifetime of $\mathrm{NO}_{2}$, thus pushing peak ozone production farther downwind.

\section{Conclusion}

These results show that the MCMA emissions have a discernible impact in regional air quality and photochemistry represented by contributing to the majority of local $\mathrm{CO}$ and $\mathrm{NO}_{2}$, along with of $10-30 \%$ of $\mathrm{CO}$ and $\mathrm{NO}_{\mathrm{y}}$ within $200 \mathrm{~km}$. Broader geographical MCMA impacts (some $900 \mathrm{~km}$ Northeast of the city) are shown for specific outflow conditions (19 March 2006, C-130 flight) in which enhanced ozone, $\mathrm{NO}_{\mathrm{y}}$, and MTBE mixing ratios over the Gulf of Mexico are linked to MCMA by tagged tracers using a chemical transport model, which captured the majority of observations with little bias and high correlation coefficient. The effect of aerosols on photochemistry and ozone formation can be large; e.g., photolysis rates of $\mathrm{NO}_{2}$ can be reduced regionally by up to $40 \%$, while ozone formation can be reduced by $5-10 \%$ near the surface. In addition, observed ozone production efficiency is lower near MCMA $(<100 \mathrm{~km})$ than surrounding areas. Similarly airmasses under large MCMA influence also show lower ozone production efficiency than those with smaller MCMA influence. This research shows that MCMA emissions impact the regional environment in important ways with broad influences on air quality, photochemistry, and ozone production. However, these influ- ences vary significantly with synoptic conditions, also becoming more subtle with distance. Thus the establishment of the air pollution footprint of megacities in general, and MCMA specifically, is a challenging problem, and one that cannot be determined by observations themselves. Here we show that the use of novel interpolation of aircraft observations through kriging, in conjunction with model products, can provide geographical context and qualitative categorization of the influence of MCMA emissions. While there are inherent uncertainties in models in terms of boundary conditions, emissions inventories, and transport, these have been evaluated and support insight provided by these. This research shows that while MCMA emissions have a discernible effect on regional air quality and photochemistry, both contributing large amounts of ozone and its precursors (10-30\% modeled enhancements), and aerosol concentrations that hinder formation of ozone to its potential due to its reduction in regional photolysis rates.

Acknowledgements. This work was funded in part by research grants by NASA and NSF (ATM Award 0528227 to MIT). Special thanks to the MILAGRO science team for providing high quality chemical observations in a timely fashion. Special thanks to Jerome Fast, Brad Pierce, Larry Kleinman, Louisa Emmons, and Sasha Madronich.

Edited by: H. Singh 


\section{References}

Achte, C., Puttman, W., and Klasmeir, J.: Compartment modeling of mtbe in the generic environment and estimations of the aquatic MTBE input in Germany using the EQC model, J. Environ. Monitor., 4, 747-752, doi:710.1039/b201879a, 2002.

Carmichael, G. R, Tang, Y., Kurata, G., Uno, I., Streets, D., Woo, J. H., Huang, H., Yienger, J., Lefer, B., Shetter, R., Blake, D., Atlas, E., Fried, A., Apel, E., Eisele, F., Cantrell, C., Avery, M., Barrick, J., Sachse, G., Brune, W., Sandholm, S., Kondo, Y., Singh, H., Talbot, R., Bandy, A., Thorton, D., Clarke, A., and Heikes, B.: Regional-scale chemical transport modeling in support of the analysis of observations obtained during the trace-p experiment, J. Geophys. Res.-Atmos., D21(8823), 1-44, doi:10.1029/2002JD003117, 2003.

Carslaw, N. and Carslaw, D.: The gas-phase chemistry of urban atmospheres, Surv. Geophys., 22, 31-53, 2001.

Carter, W. P. L.: Documentation of the SAPRC-99 chemical mechanism for voc reactivity assessment, final report to California Air Resources board, Contract No. 92-329, University of California, Riverside, USA, 8 May 2000.

Emmons, L., Pfister, G., Madronich, S., et al.: Impact of Mexico City emissions on regional air quality from mozart-4 simulations, in preparation, 2009.

Fast, J. D., de Foy, B., Acevedo Rosas, F., Caetano, E., Carmichael, G., Emmons, L., McKenna, D., Mena, M., Skamarock, W., Tie, X., Coulter, R. L., Barnard, J. C., Wiedinmyer, C., and Madronich, S.: A meteorological overview of the MILAGRO field campaigns, Atmos. Chem. Phys., 7, 2233-2257, 2007, http://www.atmos-chem-phys.net/7/2233/2007/.

Geron, C., Guenther, A., and Pierce, T.: An improved model for estimating emissions of volatile organic compounds from forests in the Eastern United States, J. Geophys. Res.-Atmos., 99(D6), 12773-12792 doi:12710.11029/12794JD00246, 1994.

Grell, G., Dubhia, J., and Stauffer, D. R.: Description of the Fifth Generation Penn State/NCAR Mesoscale Model (MM5), http: //cng.ateneo.net/cng/wyu/resources/mm5/desc/cover.pdf, last access: June 2006, 1995.

Grell, G. A., Peckham, S. E., Schmitz, R., McKeen, S. A., Frost, G., Skamarock, W. C., and Eder, B.: Fully coupled "Online" Chemistry within the WRFmodel, Atmos. Environ., 39, 69576975, 2005.

Gurjar, B. R. and Lelieveld, J.: New directions: Megacities and global change, Atmos. Environ., 39, 391, 2005.

Gurjar, B. R., Butler, T. M., Lawrence, M. G., and Lelieveld, J.: Evaluation of emissions and airquality in megacities, Atmos. Environ., 42, 1593-1606, 2008.

Guttikunda, S. K., Tang, Y. H., Carmichael, G. R., Kurata, G., Pan, L., Streets, D. G., Woo, J. H., Thongboonchoo, N., and Fried, A.: Impacts of Asian megacity emissions on regional air quality during spring 2001, J. Geophys. Res.-Atmos., 110(D20), 1-27, 2005.

Guttikunda, S. K., Carmichael, G. R., Calori, G., Eck, C., and Woo, J.-H.: The contribution of megacities to regional sulfur pollution in Asia, Atmos. Environ., 37(11), 11-22, 2003.

Hong, S.-Y., Noh, Y., and Dudhia, J.: A new vertical diffusion package with an explicit treatment of entrainment processes, Mon. Weather Rev., 134, 2318-2341, 2006.

Horowitz, L. W., Walters, S., Mauzerall, D., et al: A global simulation of tropospheric ozone and related tracers: Description and evaluation of MOZART, version 2, J. Geophys. Res.-Atmos., 108(D24), 4784, doi:4710.1029/2002JD002853, 2003.

Kim, Y. P. and Seinfeld, J. H.: Atmospheric gas-aerosol equilibrium iii: Thermodynamics of crustal elements $\mathrm{Ca}^{2+}, \mathrm{K}^{+}, \mathrm{Mg}^{2+}$, Aerosol Sci. Tech., 22, 93-110, 1995.

Kim, Y. P., Seinfeld, J. H., and Saxena, P.: Atmospheric gas-aerosol equilibrium i: Thermodynamic model, Aerosol Sci. Tech., 19, 151-181, 1993.

Kim, Y. P., Seinfeld, J. H., and Saxena, P.: Atmospheric gas-aerosol equilibrium ii: Analysis of common approximations and activity coefficient calculation methods, Aerosol Sci. Tech., 19, 182-198, 2003.

Kleinman, L., Daum, P., Lee, Y., Nunnermacker, L., and Springton, S.: Ozone production efficiency in an urban area, J. Geophys. Res.-Atmos., 107, 4733, 2002.

Krige, D. G.: A statistical approach to some mine valuations and allied problems at the Witwatersrand, Master's Thesis of the University of Witwatersrand, The Netherlands, 1951.

Kuhns, H. and Vukovich, K. E.: JM Development of a United States-Mexico emissions inventory for the big bend regional aerosol and vility observationsl (bravo) study, of the Air Waste Management Association, 55, 677, 677-692, 2005.

Li, G., Zhang, R., Fan, J., and Tie, X.: Impacts of black carbon aerosol on photolysis frequencies and ozone in the houston area, J. Geophys. Res.-Atmos., 110, D23206, doi:10.1029/2005JD005898, 2005.

Lynn, W.: Megacities: Sweet dreams or environmental nightmares?, Environ. Sci. Technol., 33, 238A-240A, 1999.

Madronich, S.: Implications of recent total atmospheric ozone measurements for biologically active ultraviolet-radiation reaching the earths surface, Geophys. Res. Lett., 19, 37-40, 1992.

Madronich, S.: Chemical evolution of gaseous air pollutants downwind of tropical megacities: Mexico City case study, Atmos. Environ., 40, 6012, doi:10.1016/j.atmosenv.2005.08.047, 2006.

Mage, D., Ozolins, G., Peterson, P., Webster, A., Orthofer, R., Vandeweerd, V., and Gwynne, M.: Urban air pollution in megacities of the world, Atmos. Environ., 30, 681, doi:10.1016/13522310(95)00219-7, 1996.

Marley, N. A., Gaffney, J. S., Ramos-Villegas, R., and Cárdenas González, B.: Comparison of measurements of peroxyacyl nitrates and primary carbonaceous aerosol concentrations in Mexico City determined in 1997 and 2003, Atmos. Chem. Phys., 7, 2277-2285, 2007, http://www.atmos-chem-phys.net/7/2277/2007/.

Mayer, H.: Air pollution in cities, Atmos. Environ., 33, 4029, doi:10.1016/S1352-2310(99)00144-2, 1999.

Mena-Carrasco, M., Tang, Y., Carmichael, G., et al.: Improving regional ozone modeling through systematic evaluation of errors using the aircraft observations during the International Consortium for Atmospheric Research on Transport and Transformation, J. Geophys. Res.-Atmos., 112, D12S19, doi:10.1029/2006JD007762, 2007.

Mena, M.: Improving emissions inventories in North America through systematic analysis of model performance during ICARRT and MILAGRO, Doctoral dissertation, The University of Iowa, Iowa City, USA, (http://etd.lib.uiowa.edu/2007/mmena. pdf), 2007

Molina, L. T., Kolb, C. E., de Foy, B., Lamb, B. K., Brune, W. H., Jimenez, J. L., Ramos-Villegas, R., Sarmiento, J., 
Paramo-Figueroa, V. H., Cardenas, B., Gutierrez-Avedoy, V., and Molina, M. J.: Air quality in North America's most populous city - overview of the MCMA-2003 campaign, Atmos. Chem. Phys., 7, 2447-2473, 2007,

http://www.atmos-chem-phys.net/7/2447/2007/.

Molina, L. T. and Molina, M.: Air quality in Mexico megacity, an integrated assessment, published by Kluwer, 4-5, 2002.

NCEP: The global forecasting system, NCEP Office Note 442, http://www.emc.ncep.noaa.gov/mmb/gcp/noahlsm/README2. 2.htm, 2003.

NOAA: The community NOAH land surface model, Users Guide Public Version 2.7.1, http://www.emc.ncep.noaa.gov/mmb/gcp/ noahlsm/NoahLSMUSERGUIDE2.7.1.htm, 2005.

Olivier, J. G. J., Maas, B. A., van der, C. W. M., Berdowski, J. J. M., Veldt, C., Bloos, J. P. J., Visschedijk, A. J. H, Zandveld, P. Y. J., and Haverlag, J. L: Application of EDGAR, RIVM report 73301001, 2267-2288, 2002.

Pfister, G., Hess, P. G., Emmons, L. K., Lamarque, J.F.,Wiedimeyer, C., Edwards, C. P., Petron, G., Gille, J. C., and Sachse, G. W.: Quantifying co emissions from the 2004 Alaskan wildfires using MOPITT-CO data, Geophys. Res. Lett., 32, L11809, doi:11810.11029/12005GL022995, 2005.

Pierce, R. B., Olivier, J., Bouwman, A., van der Maas, C., Berdowski, J., Veldt, C., Bloos, J., Visschedijk, A., Zandveld, P., and Haverlag, J.: Regional air quality modeling system (RAQMS) predictions of the tropospheric ozone budget over East Asia, J. Geophys. Res.-Atmos., 108(D21), 8825, doi:10.1029/2002jd003176, 2003.
Pierce, R. B., Schaack, T., Al-Saadi, J. A., et al.: Chemical data assimilation estimates of continental US Ozone and nitrogen budgets during the Intercontinental Chemical Transport Experiment - North America, J. Geophys. Res.-Atmos., 112(D21), D12S21, doi:10.1029/2006JD007722 2007.

Raga, G. B., Castro, T., and Baumgardner, D.: The impact of megacity pollution on local climate and implications for the regional environment: Mexico City, Atmos. Environ., 35, 1805, doi:10.1016/S1352-2310(00)00275-2, 2001.

Saier, M. H.: Are megacities sustainable?, Water Air Soil Poll., 191, $1-3,2008$.

Tang, Y. H., Carmichael, G. R., Uno, I., et al.: Impacts of aerosols and clouds on photolysis frequencies and photochemistry during trace-p: 2. Three-dimensional study using a regional chemical transport model, J. Geophys. Res.-Atmos., 108(D21), 8822, doi:10.1029/2002JD003100, 2003.

Tie, X., S. M., G. Li, Z. Ying, R., Zhang, A., Garcia, R., Lee-Taylor, J., and Liu, Y.: Characterizations of chemical oxidants in Mexico City: A regional chemical dynamical model (WRF-CHEM), Atmos. Environ., 41, 1989-2008, 2007.

Valentine, G. A. and Heiken, G.: The need for a new look at cities, Environ. Sci. Pol., 3, 231-234, 2000. 